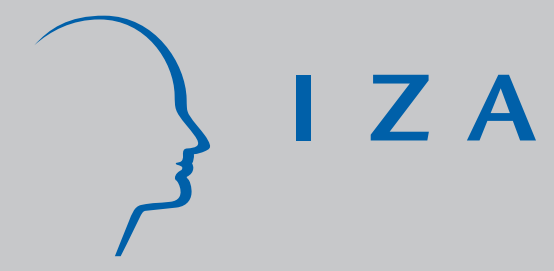

IZA DP No. 833

Structural Reforms and the Macroeconomy:

The Role of General Equilibrium Effects

Hans Gersbach

J uly 2003 


\title{
Structural Reforms and the Macroeconomy: The Role of General Equilibrium Effects
}

\author{
Hans Gersbach \\ University of Heidelberg and IZA Bonn
}

\author{
Discussion Paper No. 833 \\ July 2003
}

IZA

P.O. Box 7240

D-53072 Bonn

Germany

Tel.: +49-228-3894-0

Fax: +49-228-3894-210

Email: iza@iza.org

This Discussion Paper is issued within the framework of IZA's research area Internationalization of Labor Markets. Any opinions expressed here are those of the author(s) and not those of the institute. Research disseminated by IZA may include views on policy, but the institute itself takes no institutional policy positions.

The Institute for the Study of Labor (IZA) in Bonn is a local and virtual international research center and a place of communication between science, politics and business. IZA is an independent, nonprofit limited liability company (Gesellschaft mit beschränkter Haftung) supported by Deutsche Post World Net. The center is associated with the University of Bonn and offers a stimulating research environment through its research networks, research support, and visitors and doctoral programs. IZA engages in (i) original and internationally competitive research in all fields of labor economics, (ii) development of policy concepts, and (iii) dissemination of research results and concepts to the interested public. The current research program deals with (1) mobility and flexibility of labor, (2) internationalization of labor markets, (3) welfare state and labor market, (4) labor markets in transition countries, (5) the future of labor, (6) evaluation of labor market policies and projects and (7) general labor economics.

IZA Discussion Papers often represent preliminary work and are circulated to encourage discussion. Citation of such a paper should account for its provisional character. A revised version may be available on the IZA website (www.iza.org) or directly from the author. 
IZA Discussion Paper No. 833

July 2003

\section{ABSTRACT}

\section{Structural Reforms and the Macroeconomy: The Role of General Equilibrium Effects*}

We examine the macroeconomic consequences of industry wage bargaining and product market reforms. We suggest that general equilibrium effects may be important for the evaluation of industry-specific regulations. In particular, we suggest that the European unemployment problem can be traced back partially to insufficient recognition of general equilibrium effects. Moreover, unawareness of general equilibrium effects may be an explanation of why regulations are introduced and why structural reforms are (not) undertaken.

JEL Classification: D58, E24, J50, L50, O33

Keywords: industry wage bargaining, structural reforms, general equilibrium effects, uneven technological progress, unemployment

Hans Gersbach

Alfred-Weber-Institut

University of Heidelberg

Grabengasse 14

69117 Heidelberg

Germany

Email: gersbach@uni-hd.de

\footnotetext{
* Invited Lecture at the congress of the International Economic Association, Lisbon, September 2003. I would like to thank Martin N. Baily, Heino Fassbender, Hans Haller, Verena Liessem, Christoph M. Schmidt, George Sheldon, Robert Solow, Jan Wenzelburger, conference participants at the annual meeting of the German Economic Association in Mainz 1999 and at the annual meeting of the European Economic Association (EEA) in Lausanne 2001, and seminar participants in Heidelberg and Bonn for helpful comments and suggestions on this line of inquiry.
} 


\section{Introduction}

Structural reforms in factor and product markets have been at the top of the policy agenda in the last few decades. Prominent examples are product market reforms in a variety of service industries in industrial countries, labor market reforms in Europe, and worldwide regulation of banking in the form of Basel I and II.

Structural reforms are attempts to eliminate market rigidities or to correct market failures. This paper is concerned with the macroeconomic consequences involved when such reforms concern a subset of industries in an economy. The key issues of this line of inquiry are:

- Do changes in a subset of industries (caused by regulation or other factors) have substantial macroeconomic consequences that may differ from industry effects?

- How should regulation take account of such macroeconomic effects?

- Could the unawareness of general equilibrium effects explain

- why certain structural reforms take place, and

- why certain structural reforms are not tackled?

- Can and should monetary policy complement structural reforms?

We will focus on the first three questions and consider two important cases.

The first example is concerned with industry wage bargaining. We show that insufficient recognition of general equilibrium effects causes industry unions and employers to settle for high-wage agreements associated with high unemployment. Unawareness of general equilibrium effects can thus considerably reinforce the impact of particular labor market institutions, such as industry wage bargaining, on unemployment.

In the second example, we consider product market reforms associated with large productivity gains. We show that, while sectoral employment may decline, aggregate employment increases under standard production specifications. Therefore, the concern that employment will decline when technical progress in an industry takes place 
as a consequence of deregulation is not justified if general equilibrium effects are properly taken into account. Aggregate employment may decline, however, in various other circumstances.

Both examples illustrate the following points:

- Macroeconomic effects of structural reforms in a subset of markets may be quite different from sectoral effects.

- Awareness of general equilibrium effects may be important for the evaluation of industry-specific regulations. ${ }^{1}$

- In particular, regulators' unawareness of general equilibrium effects may provide explanations of why regulations are introduced or why structural reforms are (not) undertaken.

The theme of this paper is developed by drawing upon asymmetric multi-sector general equilibrium models with specific institutions and regulations in an industry, as outlined e.g. in Gersbach and Schniewind (2001) and (2002) . The paper is organized as follows. In the next section, we discuss the case of industry wage bargaining. In Section 3, we examine product market reforms and unemployment. In Section 4, we place our findings in a broader context and draw conclusions.

\section{Example 1: Industry Wage Bargaining}

\subsection{The Problem}

In the first case, we consider industry wage bargaining and its impact on unemployment. There is a vast literature on labor market institutions and unemployment, in particular in the European context, and we will not try to summarize it here. We add a further line of reasoning on the question of why particular labor market institutions may lead to high unemployment.

\footnotetext{
${ }^{1}$ Clearly, the absolute magnitude of partial and general equilibrium effects in macroeconomic terms depends on the size of the industry under consideration. However, the relative contribution of partial and general equilibrium effects to the macroeconomic change caused by industry-specific regulation is not primarily a matter of size.
} 
We examine how the ability of bargaining parties to identify general equilibrium effects influences wages and unemployment at the aggregate level. ${ }^{2}$ We suggest that the obstinacy of the European unemployment problem may be traced back partially to insufficient recognition of general equilibrium effects.

\subsection{The Model}

We present the underlying two-sector general equilibrium model with the following figure. ${ }^{3}$

Figure 1: Model

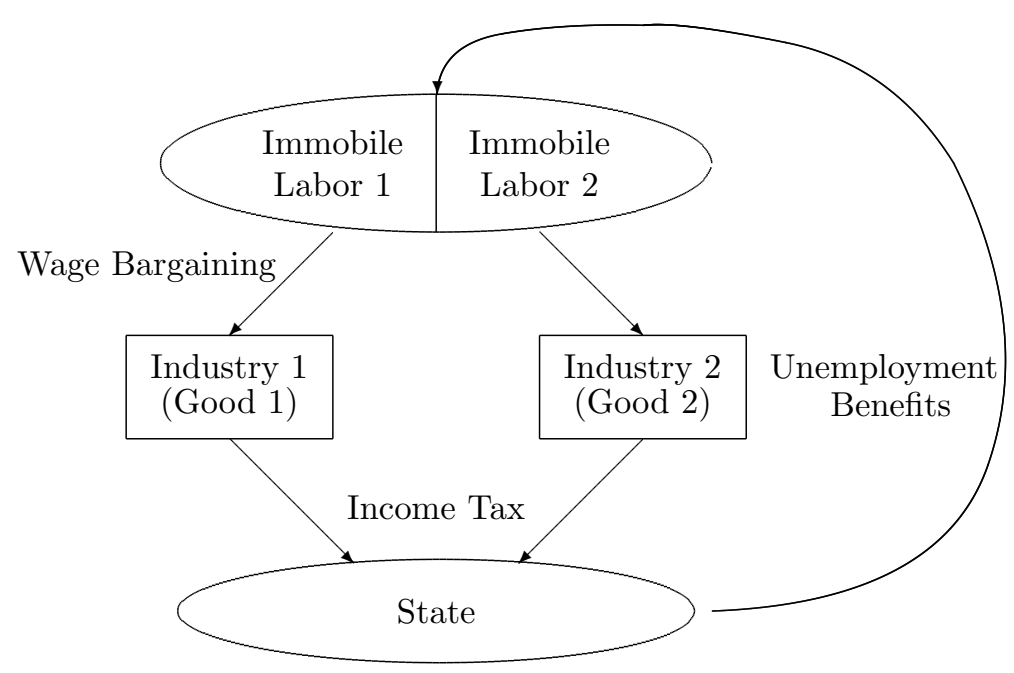

There are two industries producing good 1 and good 2 respectively, using immobile labor. We consider wage bargaining in industry 1, assuming in the simplest case an exogenously given real wage in industry 2. The general thrust of our argument also holds if the wages in industry 2 are flexible or are themselves determined by wage bargaining. If there is unemployment in the economy, it is financed by a flat tax on income and governments are forced to balance the budget.

\footnotetext{
${ }^{2}$ Our procedure in this paper is closely related to the learning and bounded rationality perspective in economics. Although our focus on the level of recognition of general equilibrium effects appears to be the first modeling attempt, our equilibrium concept uses the notion of self-confirming equilibria widely used in different variants in the learning literature, surveyed e.g. in Evans and Honkapohja (1999), Fudenberg and Levine (1996) and Sargent (1993).

${ }^{3} \mathrm{~A}$ formal presentation of the model and the results can be found in Gersbach and Schniewind (2001).
} 


\subsection{Bargaining Processes}

We consider collective bargaining between a union and an employers' association in industry 1 . The general objective function, denoted by $\Gamma$, resulting from the Nashbargaining product, is given as follows:

$$
\Gamma=\frac{w_{1}-u b}{p\left(p_{1}, p_{2}\right)} L_{1} \frac{\pi_{1}}{p\left(p_{1}, p_{2}\right)}=\underbrace{\frac{w_{1}-u b}{p\left(p_{1}, p_{2}\right)} L_{1}}_{\begin{array}{l}
\text { real value of } \\
\text { additional in- } \\
\text { come for union } \\
\text { members }
\end{array}} \cdot \underbrace{\frac{p_{1} q_{1}-w_{1} L_{1}}{p\left(p_{1}, p_{2}\right)}}_{\text {real profits }}
$$

The variables $p_{1}$ and $p_{2}$ denote the good prices, $L_{1}$ is employment and $q_{1}$ is output in industry 1. $p$ is an appropriate consumer price index. The nominal wage $w_{1}$ in industry 1 is the choice variable of the bargaining parties. Finally, $u b$ denotes nominal unemployment benefits and we assume that real unemployment benefits are fixed by the government. As a result, the objective function of cooperative bargaining of unions and employers is the product of real profits in the industry and the real value of income of union members over real unemployment benefits, assuming that all employed workers in industry 1 are unionized. ${ }^{4}$

For nominal wage setting to have real effects, we assume $p_{2}=1$ and thus bargaining parties determine the wage in terms of good 2. The key question is which variable changes are taken into account by bargaining agents. There are at least three conceivable bargaining processes, summarized in table 1.

Under myopic bargaining (MB), the union and the industry association only take into account the change in employment in industry 1 associated with a change in wage $w_{1}$ while assuming all other variables to stay constant. Under partial equilibrium bargaining (PEB), bargaining agents consider employment and price effects in industry 1 but assume that nominal unemployment benefits and all the other variables in the economy will remain unchanged when they vary $w_{1}$. In particular, all prices and quantities in industry 2 are assumed to stay constant. Finally, when agents determine

\footnotetext{
${ }^{4}$ Other plausible outside options in the Nash-bargaining framework would lead to similar effects.
} 
Table 1: Bargaining Processes

\begin{tabular}{|l|c|c|}
\hline Bargaining process & $\begin{array}{c}\text { Variable changes } \\
\text { considered }\end{array}$ & $\begin{array}{c}\text { Variable changes } \\
\text { not considered }\end{array}$ \\
\hline \hline Myopic Bargaining (MB) & $L_{1}\left(w_{1}\right)$ & $p_{1}, p, u b$, industry 2 \\
Partial Equilibrium Bargaining (PEB) & $L_{1}\left(w_{1}\right), p_{1}\left(w_{1}\right), p\left(w_{1}\right)$ & $u b$, industry 2 \\
General Equilibrium Bargaining (GEB) & All variables & \\
\hline
\end{tabular}

$w_{1}$ under general equilibrium bargaining (GEB), they take into account all resulting changes in industry 1 , industry 2 and in $u b .^{5}$

\subsection{Results and Interpretation}

\subsubsection{Main Result}

By considering equilibrium wages $w_{1}$ and the resulting unemployment denoted by $U$ as a mapping from the set of bargaining processes to the real numbers, we can state the main result as follows:

\section{Main Result}

(i) $w_{1}^{P E B}>w_{1}^{G E B}$ and $U(P E B)>U(G E B)$

(ii) $w_{1}^{P E B}>w_{1}^{M B}$ and $U(P E B)>U(M B)$

The result is summarized in Figure 2, which relates the degree of farsightedness to wages and unemployment.

The main result is orthogonal to a well-known observation in labor economics. In an economy with highly decentralized wage negotiations, wages and unemployment are

\footnotetext{
${ }^{5}$ The only variable assumed (incorrectly) to remain constant is the tax rate and thus this private sector GEB assumes a constant state sector. If tax effects were taken into account, bargaining agents would even be more cautious in wage setting under this complete form of GEB.
} 
Figure 2: Degrees of Farsightedness and Unemployment

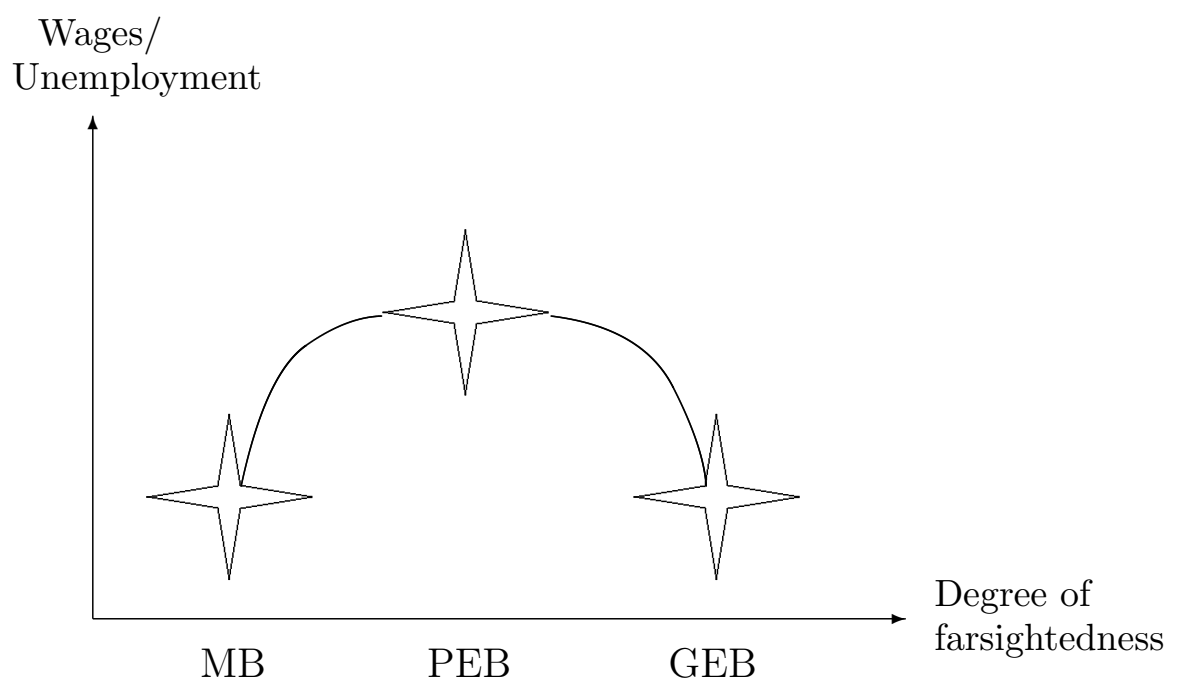

quite low, whereas in an economy with more centralized wage-bargaining, wages and unemployment are high; in economies with totally centralized wage settings, wages and unemployment are again quite low (Calmfors and Driffill (1988)). Taking demand as exogenously given, Calmfors and Driffill do not need to take account of feedback effects from the demand side. They vary the number and size of industries and with them the degree of bargaining centralization; by contrast, we vary the degree of farsightedness, also obtaining a hump-shaped curve for wages and unemployment respectively.

\subsubsection{PEB versus GEB}

We provide the intuition why $w_{1}^{P E B}$ is higher than $w_{1}^{G E B}$. Under the PEB view, agents recognize that a higher wage implies less employment. The agents are aware that a lower level of employment implies less output and thus a rise in the price $p_{1}$ and accordingly in $p$. Everything else is assumed to stay constant.

What unions and employers in the first industry do not perceive within PEB are the feedbacks from industry 2 . In industry 2 , where nominal wages $w_{2}$ are kept such that real wages $w_{2} / p$ stay constant, the rise in the price index must lead to a rise in the nominal wage. In turn, higher nominal wages in industry 2 lead to a decline of labor demand in industry 2 , so that employment and output in industry 2 decrease as well. 
This causes a rise in $p_{2}$ relative to $p_{1}$, i.e. a fall of $p_{1}$. A decline in $p_{1}$ of course leads to lower profits in industry 1 (which interferes with the employers' objectives) and lower employment (counter to the union's objectives). Less employment in the first industry then leads to less output and a higher price $p_{1}$, leading in turn to a higher price index, which causes higher wages in industry 2 , again leading to less labor demand in industry 2 , and so on.

All these interactions with the other industry exacerbate the consequences of high wages in industry 1 but are not taken into account by agents restricted to the PEB view. Furthermore, a higher price index implied by a higher wage does not only lead to a rise in $w_{2}$, but also to a rise in $u b$. Although this also depreciates the value of the union's objective function, it is not perceived from a PEB perspective.

To summarize, in PEB, as opposed to GEB, the underestimation of these negative employment and benefits effects, plus the overestimation of the positive price effect that follows from high wages, lead to a shift to the right in the maximum of the objective functions and thereby to a higher wage agreement, which in turn involves higher unemployment. Table 2 summarizes both the estimations of variables under PEB relative to GEB and the consequences for employment and output.

Table 2: Estimations and Impacts under PEB/ GEB

\begin{tabular}{|l|l|l|}
\hline Variable & $\begin{array}{l}\text { Estimation un- } \\
\text { der PEB rela- } \\
\text { tive to GEB }\end{array}$ & $\begin{array}{l}\text { Impact on em- } \\
\text { ployment and } \\
\text { output under } \\
\text { PEB relative to } \\
\text { GEB }\end{array}$ \\
\hline \hline$p_{1}, p$ & overestimated & negative \\
$L_{1}$ & overestimated & negative \\
$u b$ & underestimated & negative \\
\hline
\end{tabular}




\subsubsection{PEB versus $\mathrm{MB}$}

The situation is different when we compare MB and PEB. Ignoring general equilibrium effects leads to bad outcomes under $\mathrm{PEB}$, but ignoring them and further partial equilibrium effects leads to cautious wage setting. While under PEB both employment and price reactions are considered, agents with a $\mathrm{MB}$ view consider only employment reactions. This adversely affects the union's and the employers' objectives because a reduction of labor means a reduction of both the wage bill and the profits from lower output. The rise in price (due to less employment and therefore less output) is not considered by agents under MB. A high price $p_{1}$ increases both profits and employment, thus boosting both the union's and the employers' objectives. Since this positive impact is not taken into account, unions and employers are very cautious and negotiate lower wages under MB than under PEB. Hence, wages and unemployment are lower under MB than under PEB.

\subsection{Discussion}

A brief discussion of the significance of the main result is called for. First, the equilibrium under $\mathrm{MB}$ and $\mathrm{PEB}$ may also be interpreted as the steady state of an adaptive learning process in the following way. If the agents started at any equilibrium $E\left(w_{1}\right)$ and then negotiated wages, the PEB and MB bargaining processes would lead to a sequence of wages where the equilibrium in the last period is the initial condition for the next bargaining process. Approaching the PEB or MB equilibrium can then be interpreted as the convergence of a learning process. ${ }^{6}$

Second, the thrust of our results is robust when wage negotiations occur in both industries or when wages are flexible in the second industry. Flexible wages in industry 2 alleviate the detrimental consequences from a PEB view, but wages and unemployment remain higher under PEB than under GEB or MB. Therefore, high unemployment under PEB appears to be a robust phenomenon.

The intermediate view PEB might be the most plausible for those countries where wages are negotiated at the industry level. Considering all general equilibrium effects may

\footnotetext{
${ }^{6}$ Simulations of such learning processes are available upon request.
} 
be too demanding in industry wage negotiation. In this case, our results suggest that firm-level wage bargaining which is plausibly associated with MB would be preferable to industry-level bargaining.

\section{Example 2: Product Market Reforms, Uneven Technological Progress and Unemployment}

\subsection{The Problem}

Product market reforms are concerned with promoting competition in industries by deregulation or appropriate regulation. Often such reforms yield large total factor productivity (tfp) gains. The productivity and employment effects of such product market reforms are the theme of a number of studies from the McKinsey Global Institute. ${ }^{7}$ Two recent examples of these studies in which product market reforms have led to large productivity gains can serve as illustrations:

- Relaxing entry barriers and privatization in fixed telephone services in Europe.

- Elimination of trade protection for the French automotive industry.

The relationship between market power and productivity has been investigated in a variety of papers. In particular, Green and Mayes (1991), Hay and Liu (1997) and Nickell $(1996,1999)$ provide evidence that on average productivity levels or growth rates are negatively correlated with market power.

Although total factor productivity improvements are the most important source of economic growth, rising sectoral productivity is often associated with job destruction in the industry under consideration and may therefore lead to opposition from workers. Such opposition may prove to be so strong that product market reforms are not undertaken. Therefore, the key questions are:

- Do product market reforms yielding uneven technological progress raise aggregate employment - contrary to the "conventional wisdom"?

\footnotetext{
${ }^{7}$ See for example MGI (2002) and also Baily and Solow (2001), Baily (1993) and Baily and Gersbach (1995).
} 
- Might unawareness of general equilibrium effects explain the lack of product market reforms?

The issues are related to recent work ${ }^{8}$ by Blanchard (1998) and Cohen and SaintPaul (1997), who have pointed out that uneven technical progress may lead to higher unemployment when technical progress widens the productivity differential between different sectors. We focus on short-term effects and general equilibrium repercussions. Gersbach (2000) provides a survey on whether product market reforms might help to reduce unemployment in Europe. ${ }^{9}$

\subsection{Model and Analysis}

The model for studying the questions at hand is an extended variant of the two-sector economy introduced in the last section, with labor and capital allowing for different types of labor with respect to skill levels and mobility. Labor market frictions such as real wage rigidities ${ }^{10}$ in each industry cause unemployment. We examine how technical progress in industry 1 impacts on employment. Four combinations can occur:

- sector employment $\downarrow$, aggregate employment $\downarrow$

- sector employment $\downarrow$, aggregate employment $\uparrow$

- sector employment $\uparrow$, aggregate employment $\downarrow$

- sector employment $\uparrow$, aggregate employment $\uparrow$

Within an asymmetric general equilibrium we can identify the conditions under which a particular case occurs.

\footnotetext{
${ }^{8}$ The question of how productivity improvements in one industry affect employment in the economy is by no means new. The modern answers date back at least to Baumol (1967). But Baumol did not focus on labor market rigidities. New growth theory has provided a variety of new insights into longterm relationships between market power, growth and unemployment (see Aghion and Howitt (1994) and (1998) and Peretto (2000)).

${ }^{9}$ The interaction between product market and labor market frictions plays a considerable role in the New Keynesian Economics (see Mankiw and Romer (1991), Dixon and Rankin (1995)), which focuses on various types of market rigidities as well as deviations from perfect competition as causes or amplifiers of economic fluctuations and indicates the potential role of macroeconomic policies.

${ }^{10}$ Qualitatively our arguments hold when labor market regulations are aggregate welfare-improving on grounds not incorporated in the model, such as unemployment insurance.
} 


\subsection{Results}

We provide two benchmark results.

(i) If all production functions are of the same Cobb-Douglas type and if workers are mobile, a rise of productivity in industry 1 always raises aggregate employment.

(ii) If all production functions are of the same Cobb-Douglas type and if workers are immobile and the elasticity of substitution between the goods is not too high, a rise of productivity in industry 1 raises aggregate employment until full employment is achieved in the other industry. If there is full employment in the other sector, aggregate employment may decline.

The intuition which we provide for the first case is important in order to gain an understanding of how general equilibrium forces are at work. As the productivity of industry 1 rises, production of good 1 (and good 2) rises as well, in line with an increase in aggregate real income. The same Cobb-Douglas functions in both industries imply that the factor income distribution must remain as before. When real wages are fixed, more real income on labor means that more people must be employed in the economy. The benchmark results illustrate that, independently of the elasticity of substitution on the demand side, aggregate employment can increase. The elasticity of substitution determines how the employment effects are distributed across industries. This line of reasoning illustrates the importance of incorporating general equilibrium effects when product market reforms are considered. In the benchmark cases, employment in a deregulated industry may decline, but aggregate employment increases and the concerns of workers at the total economy level are unjustified.

The result can be extended to a variety of circumstances. But caution is necessary in drawing more general conclusions. There are a variety of circumstances where product market reforms inducing uneven technological progress do lower employment. Notably, when the elasticity of substitution among factors of production and among commodities in demand is small, any type of uneven technological progress (tfp, labor saving or capital saving) can cause employment to decline as discussed in detail in Gersbach 
and Schniewind (2002). Therefore, the overall positive assessment of the impact of product market reforms on employment as discussed in Gersbach (2000) rests on the assumption that substitution elasticities in the economy are not too low.

\section{Conclusion}

The main conclusion we can draw from our examples is that general equilibrium effects are an important ingredient of industry-specific deregulation or regulation. Beyond the questions of robustness, a number of important issues remain which we address in the following.

First, as suggested by Gersbach and Sheldon (1996), there may be important complementarities between product market and labor market reforms, operating again through general equilibrium effects. This could be important for the feasibility of the political implementation of reforms discussed below. Moreover, there are a variety of further interactions between product and labor market reforms. Amable and Gatti (2001) show that an increase in product market competition boosts the hiring and the separating rate in an efficiency wage model. Blanchard and Giavazzi (2001) show how deregulation in product and labor markets reduces and redistributes rents. Such knowledge is central to the understanding of the economic path taken by countries that have or have not embarked on broad reforms.

Second, should monetary policy complement structural reforms over and above reactions induced by standard policy rules (e.g. inflation targeting and interest rate rules)? This thorny issue was taken up early by Hellwig and Neumann (1987) and is a central theme of the contribution of Malinvaud (2003) (see also Bean (1998)). While there may be a case for coordination of labor market reforms and monetary policy, the usual staggard structure of product market reforms and hence the absence of large-scale reforms at a particular point in time renders special monetary-policy reactions to particular reforms irrelevant.

Third, the political feasibility of implementing reforms and its associated reform design problem remain legitimately at the top of the research agenda. Important insights have 
been achieved in the last decade. For instance, Saint-Paul (1995) and (2000) has argued that the redistributive goals motivating labor market institutions in Europe can be achieved at a much lower cost by using more traditional tax and transfer instruments. However, the current level of regulation can be explained by a political equilibrium, since there is a bias towards maintaining the status quo. As argued in Coe and Snower (1997) for the labor market and in Gersbach and Sheldon (1996) for the combination of product and labor market reforms, broad reform packages can internalize complementarities across reform steps. However, such programs remain unstable against the formation of coalitions lobbying for specific exemptions. Nevertheless, product market reforms may lower the bias towards the status quo in democracies (see Gersbach (1993)) with respect to labor market reforms.

Finally, the new design proposal to combine incentive contracts and democratic elections (e.g. Gersbach (2002)) may be able to enlarge the set of implementable reforms and promises higher probability that the unemployment problem in Europe will be solved.

Whether market reforms actually deliver the advantages attached to them depends on the general equilibrium effects they induce. Further investigations into the allocative and distributional consequences of implemented, planned or discussed reforms may help general equilibrium considerations to play a more central role in actual policy-making. 


\section{References}

Aghion, P., And P. Howitt (1994): "Growth and Unemployment," Review of Economic Studies, 61, 477-494.

(1998): Endogenous Growth Theory. MIT University Press, Cambridge, MA.

Amable, B., And D. Gatti (2001): "The Impact of Product Market Competition on Employment and Wages," IZA Discussion Paper, No. 276.

Baily, M. (1993): "Competition, Regulation and Efficiency in Service Industries," Brookings Papers on Economic Activity: Microeconomics, 2, 71-159.

Baily, M., and H. Gersbach (1995): "Efficiency in Manufacturing and the Need for Global Competition," Brookings Papers on Economic Activity: Microeconomics, pp. $307-358$.

Baily, M., And R. Solow (2001): "International Productivity Comparisons Built from the Firm Level," Journal of Economic Perspectives, pp. 151-172.

Baumol, W. (1967): "Macroeconomics of Unbalanced Growth: The Anatomy of Urban Crisis," American Economic Review, 3, 415-426.

BEAN, C. R. (1998): "The Interaction of Aggregate-Demand Policies and Labour Market Reform," Swedish Economic Policy Review, 5 (2), 353-382.

Blanchard, O. (1998): The Economics of Post-Communist Transition. Clarendon Press, Oxford.

Blanchard, O., AND F. Giavazzi (2001): "Macroeconomic Effects of Regulation and Deregulation in Goods and Labor Markets," http://papers.ssrn.com/paper.taf?abstract_id=257542, Working Paper.

Calmfors, L., And J. Driffill (1988): "Bargaining Structure, Corporatism and Macroeconomic Performance," Economic Policy, 6, 14-61.

Coe, D. T., and D. Snower (1997): "Policy Complementaries: The Case for Fundamental Labor Market Reform," IMF Staff Papers, 44(1). 
Cohen, D., and G. Saint-Paul (1997): "Uneven Technical Progress and Job Destructions," mimeo.

Dixon, H., And N. Rankin (1995): The New Macroeconomics: Imperfect Markets and Policy Effectiveness. Cambridge University Press, Cambridge.

Evans, G., And S. Honkapohja (1999): "Learning Dynamics," in Handbook of Macroeconomics, ed. by J. Taylor, and M. Woodford. Elsevier, Amsterdam-Lausanne.

FudenberG, D., And D. Levine (1996): "Theory of Learning in Games," Draft.

Gersbach, H. (1993): "Politics and the Choice of Durability: Comment," American Economic Review, 83 (3), 670-673.

(2000): "Promoting Product Market Competition to Reduce Unemployment in Europe: An Alternative Approach?," Kyklos, 53 (2), 117-133.

(2002): "Incentive Contracts and Elections for Politicians and the DownUp Problem," in Advances in Economic Design, ed. by M. Sertel, and S. Koray. Springer-Verlag, Berlin-Heidelberg.

Gersbach, H., And A. Schniewind (2001): "Awareness of General Equilibrium Effects and Unemeployment," IZA Discussion Paper, No. 394.

_ (2002): "Uneven Technical Progress and Unemployment," IZA Discussion Paper, No. 478.

Gersbach, H., And G. Sheldon (1996): "Structural Reforms and their Implications for Macroeconomic Policies," OECD Proceedings, pp. 131-167.

Green, A., And D. Mayes (1991): "Technical Inefficiency in Manufacturing Industries," Economic Journal, 101, 523-538.

Hay, D., And G. Liu (1997): "The Efficiency of Firms: What Difference does Competition Make?," Economic Journal, 107, 597-617.

Hellwig, M., and M. Neumann (1987): "Economic Policy in Germany: Was there a Turnaround," Economic Policy, pp. 105-133. 
Malinvaud, E. (2003): "Structural Reforms Addressed to the Labour Market and Macroeconomic Policies," in this volume.

Mankiw, N., And D. Romer (1991): New Keynesian Economics. MIT Press, Cambridge, Massachusetts, Vol. 1 and 2.

MGI (2002): Productivity Performance in France and Germany - Understanding its Drivers, Including the Role of IT. McKinsey Global Institute, Frankfurt, Paris.

NiCKell, S. (1996): "Competition and Corporate Performance," Journal of Political Economy, 104, 724-746.

(1999): "Product Markets and Labour Markets," Labour Economics, 6, 1-20.

Peretto, P. (2000): "Market Power, Growth and Unemployment," Working Paper, Duke University.

Saint-Paul, G. (1995): "Some Political Aspects of Unemployment," European Economic Review, 39, 575-582.

(2000): The Political Economy of Labour Market Institutions. Oxford University Press, Oxford.

Sargent, T. J. (ed.) (1993): Bounded Rationality in Macroeconomics. Clarendon Press, Oxford. 


\section{IZA Discussion Papers}

\begin{tabular}{|c|c|c|c|c|}
\hline No. & Author(s) & Title & Area & Date \\
\hline 819 & $\begin{array}{l}\text { M. Beine } \\
\text { F. Docquier } \\
\text { H. Rapoport }\end{array}$ & $\begin{array}{l}\text { Brain Drain and LDCs' Growth: Winners and } \\
\text { Losers }\end{array}$ & 1 & $07 / 03$ \\
\hline 820 & $\begin{array}{l}\text { C. M. Cornwell } \\
\text { K. H. Lee } \\
\text { D. B. Mustard }\end{array}$ & $\begin{array}{l}\text { The Effects of Merit-Based Financial Aid on } \\
\text { Course Enrollment, Withdrawal and Completion } \\
\text { in College }\end{array}$ & 6 & $07 / 03$ \\
\hline 821 & $\begin{array}{l}\text { P. Carneiro } \\
\text { J. J. Heckman }\end{array}$ & Human Capital Policy & 6 & $07 / 03$ \\
\hline 822 & $\begin{array}{l}\text { D. Weichselbaumer } \\
\text { R. Winter-Ebmer }\end{array}$ & $\begin{array}{l}\text { The Effects of Competition and Equal Treatment } \\
\text { Laws on the Gender Wage Differential }\end{array}$ & 6 & $07 / 03$ \\
\hline 823 & A. Filippin & Discrimination and Workers' Expectations & 5 & 07/03 \\
\hline 824 & A. Filippin & $\begin{array}{l}\text { Discrimination and Workers' Expectations: } \\
\text { Experimental Evidence }\end{array}$ & 5 & $07 / 03$ \\
\hline 825 & $\begin{array}{l}\text { A. Filippin } \\
\text { A. Ichino }\end{array}$ & $\begin{array}{l}\text { Gender Wage Gap in Expectations and } \\
\text { Realizations }\end{array}$ & 5 & $07 / 03$ \\
\hline 826 & $\begin{array}{l}\text { K. T. Hansen } \\
\text { J. J. Heckman } \\
\text { K. J. Mullen }\end{array}$ & $\begin{array}{l}\text { The Effect of Schooling and Ability on } \\
\text { Achievement Test Scores }\end{array}$ & 6 & $07 / 03$ \\
\hline 827 & $\begin{array}{l}\text { H. Buddelmeyer } \\
\text { E. Skoufias }\end{array}$ & $\begin{array}{l}\text { An Evaluation of the Performance of Regression } \\
\text { Discontinuity Design on PROGRESA }\end{array}$ & 6 & $07 / 03$ \\
\hline 828 & $\begin{array}{l}\text { D. Checchi } \\
\text { T. Jappelli }\end{array}$ & School Choice and Quality & 3 & $07 / 03$ \\
\hline 829 & $\begin{array}{l}\text { J. J. Heckman } \\
\text { X. Li }\end{array}$ & $\begin{array}{l}\text { Selection Bias, Comparative Advantage and } \\
\text { Heterogeneous Returns to Education: Evidence } \\
\text { from China in } 2000\end{array}$ & 6 & $07 / 03$ \\
\hline 830 & T. J. Hatton & $\begin{array}{l}\text { Emigration from the UK, } 1870-1913 \text { and } 1950- \\
1998\end{array}$ & 1 & $07 / 03$ \\
\hline 831 & $\begin{array}{l}\text { J. H. Abbring } \\
\text { G. J. van den Berg }\end{array}$ & $\begin{array}{l}\text { Analyzing the Effect of Dynamically Assigned } \\
\text { Treatments Using Duration Models, Binary } \\
\text { Treatment Models, and Panel Data Models }\end{array}$ & 6 & $07 / 03$ \\
\hline 832 & P.-C. Michaud & Joint Labour Supply Dynamics of Older Couples & 3 & $07 / 03$ \\
\hline 833 & H. Gersbach & $\begin{array}{l}\text { Structural Reforms and the Macroeconomy: The } \\
\text { Role of General Equilibrium Effects }\end{array}$ & 2 & $07 / 03$ \\
\hline
\end{tabular}

An updated list of IZA Discussion Papers is available on the center's homepage www.iza.org. 